Федеральная служба по интеллектуальной собственности (Роспатент)

Международный научно-образовательный центр «Кафедра ЮНЕСКО по авторскому праву, смежным, культурным и информационным правам» Национального исследовательского университета «Высшая школа экономики»

Общероссийская общественная организация «Российское авторское общество»

\section{Резолюция \\ научно-практической конференции \\ с международным участием \\ «Авторско-правовые проблемы в сфере промышленной собственности» 14 апреля 2021 года}

I. Участники конференции полагают целесообразным привлечь внимание органов государственной власти к следующим проблемным вопросам:

1. Принять во внимание концепт, согласно которому именно авторство является первоисточником индивидуализации результата интеллектуальной деятельности. В этой связи предлагается рассмотреть возможность законодательного закрепления роли автора в создании секретов производства (ноу-хау), а также обозначений, которые получают охрану в качестве средств индивидуализации.

2. При разработке правовых норм учитывать особенности трансформации авторского права в цифровой среде.

3. Законодательно закрепить правовые и организационные механизмы стимулирования процесса за- рубежного патентования российских IT-разработок и иных изобретений.

4. Проработать возможность законодательного закрепления порядка использования объектов интеллектуальных прав, охраняемых одновременно как средство индивидуализации и как объект авторских или патентных прав.

5. Проработать вопрос внесения изменений в пункт 6 статьи 1252 ГК РФ в целях установления общих правил разрешения коллизии тождественных или сходных до степени смешения средств индивидуализации и результатов интеллектуальной деятельности. Предлагается соответственно расширить названную норму, закрепив в ней принцип «первый во времени - первый в праве».

6. Изучить целесообразность возвращения в ГК РФ нормы Закона РФ «Об авторском праве и смежных правах», устанавливающей, что авторское право на произведение науки, литературы и искусства возникает в силу факта его создания, в том числе, с целью установления приоритета в случае коллизии прав.

II. Участники конференции обращаются к юридическому научному сообеству с призывом обратить внимание на следующие проблемы, имеющие большое теоретическое и практическое значение.

1. С учетом особенностей правовой природы и функциональной связанности объектов авторских прав, товарных знаков и иных объектов интеллектуальной собственности, а также формирующихся на этой основе новых результатов интеллектуальной деятельности и средств индивидуализации (например, NFT-токены, интернет-мемы и т.д.) представляется целесообразным всесторонне обсудить вопрос о целесообразности внесения изменений в статью 1225 Гражданского кодекса РФ в части замены содержащегося здесь закрытого, 
исчерпывающего перечня объектов интеллектуальной собственности на открытый перечень. Такая поправка позволит, в частности, гармонизировать отечественное законодательство об интеллектуальных правах с положениями статьи 2 Стокгольмской конвенции, учреждающей Всемирную Организацию Интеллектуальной Собственности.

2. Акцентировать внимание на исследовании коллизионных аспектов авторского, патентного и информационного права.

3. Проанализировать возможность расшивки «серых 3он» на стыке институтов авторского права, промышленных образцов и товарных знаков.

4. Изучить вопрос о целесообразности устанавливать право, применимое к определению первоначального правообладателя в отсутствие соглашения сторон, следующим образом: а) для регистрируемых объектов промышленной собственности применимым правом выступает право страны первоначальной подачи заявки; б) в случае одновременной подачи заявки в нескольких странах, подачи международной заявки, применять к установлению первоначального правообладателя право каждой страны регистрации; в) для нерегистрируемых объектов промышленной собственности применять право страны, на территории которой имел место юридический факт, послуживший основанием для предоставления охрань объекту промышленной собственности и приобретения соответствующих прав.

5. Изучить правовые последствия и перспективы использования искусственного интеллекта для создания результатов интеллектуальной детальности, для охраны и защиты объектов интеллектуальных прав.

6. Обсудить научную гипотезу о возможности интерпретации результата функционирования искусственного интеллекта в качестве объекта смежных прав.
7. Всесторонне исследовать предложение о внесении изменений в статью 1295 ГК РФ в целях установления общих правил использования служебных произведений в средствах индивидуализации, исключительные права на которые принадлежат работодателю. В частности, предлагается отразить в законодательстве положение о том, что в случае отчуждения работником исключительного права на служебное произведение для последующего включения работодателем такого служебного произведения в состав товарного знака, использование такого товарного знака, после его государственной регистрации, не является использованием служебного произведения.

III. Участники конференции обращаются к предпринимательскому сообществу, к правообладателям и пользователям объектов интеллектуальных прав:

1. Учесть возможности использования интеллектуальных технологий сравнения 3D-моделей промышленных образцов как объектов интеллектуальных прав.

2. Рассмотреть невзаимозаменяемые токены (NFT) в качестве формы оборота прав интеллектуальной собственности, а также преимущества использования цифровых технологий при факультативной регистрации объектов авторского права.

3. Скорректировать практику выплаты вознаграждения за создание и использование служебных произведений с целью приведения ее в соответствие с требованиями законодательства Российской Федерации.

4. Шире пользоваться преимуществами блокчейн-технологии в сфере библиотечного и издательского дела для охраны и защиты объектов интеллектуальных прав.

5. Формировать новые модели монетизации авторских прав в сфере промышленной собственности при производстве товаров и услуг.

6. Шире использовать возможности авторско-правовой и патентной охраны в отношении архитектурных объектов. 
7. Учесть возможность регистрации имен и псевдонимов авторов в качестве средств индивидуализации.

8. Шире применять системный подход при разработке стратегии правовой охраны и коммерциализации результатов интеллектуальной деятельности, учитывая ведущую роль в этом процессе патентно-лицензионных подразделений научных и образовательных учреждений, а также специализированных организаций, оказывающих содействие авторам.

\section{IV. Участники конференции решили:}

1. Утвердить настоящую Резолюцию научно-практической конференции с международным участием «Авторско-правовые проблемы в сфере промышленной собственности».

2. Направить настоящую Резолюцию в Администрацию Президента Российской Федерации, Правительство Российской Федерации, Федеральное Собрание Российской Федерации, Суд по интеллектуальным правам, Верховный Суд Российской Федерации, федеральные органы исполнительной власти, Российское авторское общество, профильные образовательные и исследовательские организации.

3. Продолжить обсуждение коллизионных проблем правовой охраны разнородных объектов интеллектуальной собственности, для чего организовать силами Федеральной службы по интеллектуальной собственности (Роспатент) и Международного научно-образовательного центра «Кафедра ЮНЕСКО по авторскому праву, смежным, культурным и информационным правам» Национального исследовательского университета «Высшая школа экономики» тематическую научно-практическую конференцию в апреле 2022 года, приурочив ее к Международному дню книги и авторского права.

\section{НАУЧНЫЕ ХРОНИКИ}

21 декабря 2020 г. на Факультете права Национального исследовательского университета «Высшая школа экономики» прошла международная онлайн-конференция «Медийное законодательство в эпоху пандемии», организованная Международным научно-образовательным центром «Кафедра ЮНЕСКО по авторскому праву, смежным, культурным и информационным правам». В мероприятии приняли участия около 150 специалистов из России, Германии, Ирландии, Италии, Китая, Узбекистана, Финляндии, а также представителИ ОБСЕ И ЮНЕСКО.

В своей вступительной речи декан Факультета права НИУ ВШЭ, доктор юридических наук, профессор Вадим Виноградов выразил надежду, что новый 2021 год станет не только годом всеобщей вакцинации от коронавируса, но и годом быстрого восстановления привычных условий жизни и работы, в том числе в образовании и науке. Он отметил продолжение почти 30-летней традиции предновогодних научно-практических конференций, приуроченных к очередной годовщине принятия Закона РФ от 27 декабря 1991 г. «О средствах массовой информации» и как-бы подводящих итог развитию медийного законодательства в уходящем году. Профессор В.Виноградов поприветствовал участвующих в конференции авторов закона - Ю.Батурина, М.Федотова и В.Энтина, а также руководителей профильных парламентских комитетов: А.Пушкова и А.Хинштейна.

Декан Факультета коммуникаций, медиа и дизайна НИУ ВШЭ Андрей Быстрицкий в своем кратком приветственном слове обратил внимание участников дискуссии на то, что законодателям, разрабатывающим нормы регулирования функционирования СМИ, стоит 